\title{
No effect of dietary nitrate supplementation on endurance training in hypoxia
}

\author{
J. Puype, M. Ramaekers, R. Van Thienen, L. Deldicque, P. Hespel \\ Exercise Physiology Research Group, Department of Kinesiology, KU Leuven, Belgium \\ Corresponding author: Peter Hespel, PhD, Exercise Physiology Research Group, FABER - KU Leuven, Tervuursevest 101, B-3001 \\ Heverlee, Belgium. Tel: +32 16329091, Fax:+32 16329196, E-mail: peter.hespel@faber.kuleuven.be
}

Accepted for publication 20 January 2014

\begin{abstract}
We investigated whether dietary nitrate $\left(\mathrm{NO}_{3}^{-}\right)$supplementation enhances the effect of training in hypoxia on endurance performance at sea level. Twenty-two healthy male volunteers performed high-intensity endurance training on a cycle ergometer $(6$ weeks, $5 \times 30 \mathrm{~min} /$ week at 4-6 mmol/L blood lactate) in normobaric hypoxia (12.5\% $\mathrm{FiO}_{2}$ ), while ingesting either beetroot juice $[0.07 \mathrm{mmol}$ $\mathrm{NO}_{3}{ }^{-} / \mathrm{kg}$ body weight (bw)/day; $\mathrm{BR}, \boldsymbol{n}=11$ ] or a control drink $(\mathrm{CON}, n=11)$. During the pretest and the posttest, the subjects performed a 30 -min simulated time trial (TT) and an incremental $\mathrm{VO}_{2 \max }$ test. Furthermore, a biopsy was taken from $\mathrm{m}$. vastus lateralis before and after the TT. Power output during the training sessions in both
\end{abstract}

groups increased by $\sim 6 \%$ from week 1 to week 6 $(P<0.05)$. Compared with the pretest, $\mathrm{VO}_{2 \max }$ in the posttest was increased $(P<0.05)$ in CON $(5 \%)$ and BR (9\%). Power output corresponding with the $4 \mathrm{mmol} / \mathrm{L}$ blood lactate threshold, as well as mean power output during TT increased by $\sim 16 \%$ in both groups $(P<0.05)$. Muscle phospho-AMP-activated protein kinase, hypoxia inducible factor- $1 \alpha$ mRNA content, and glycogen breakdown during the TT were similar between the groups in both the pretest and the posttest. In conclusion, low-dose dietary $\mathrm{NO}_{3}^{-}$supplementation does not enhance the effects of intermittent hypoxic training on endurance exercise performance at sea level.
Altitude training is a popular ingredient in the training plan of endurance athletes preparing for sea-level competition. Different protocols for altitude training have been developed. However, "living high - training low" remains to be the most popular model because beneficial physiological effects of altitude exposure are obtained while maintaining normal training intensity during sealevel training sessions (Millet et al., 2010). The development of hypoxicators allowing to create home-based spaces in normobaric hypoxia for either rest or training, has added novel degrees of freedom to develop variable altitude training protocols to beneficially impact on sealevel performance. In this regard, over the last 10-15 years, interest in the potential of intermittent hypoxic training (IHT), while living at sea level, on functional performance in normoxia, has grown. Most studies have shown beneficial physiological adaptations in skeletal muscle due to IHT, including increased capillary and mitochondrial density and elevated glycolytic and oxidative enzyme expression (Geiser et al., 2001; Vogt et al., 2001; Zoll et al., 2006; Hoppeler et al., 2008). We recently also reported a 6-week period of intermittent sprint training in hypoxia to elevate muscle phosphofructokinase activity compared with similar training in normoxia (Puype et al., 2013). Nonetheless, while IHT seems to induce favorable myocellular adaptations, the effects on functional capacity, measured as either $\mathrm{VO}_{2 \max }$ or endurance performance at sea level, are equivocal (Hoppeler et al., 2008; Bonetti \& Hopkins, 2009; Millet et al., 2010).

There is also evidence to indicate that nitric oxide (NO) is implicated in human adaptation to hypoxia (Levett et al., 2011; Limberg et al., 2011). NO is a ubiquitous signaling molecule playing an important role in a wide variety of physiological processes in different tissues in the human body, including skeletal muscle (Stamler \& Meissner, 2001). Literature data indicate that enhanced NO production may be an important factor in human adaptation to altitude. Accordingly, wellacclimatized Tibetan highlanders exhibit elevated circulating plasma nitrite $\left(\mathrm{NO}_{2}^{-}\right)$levels, which conceivably reflects an upregulation of NO synthase (NOS) activity (Erzurum et al., 2007a). Besides this endogenous pathway, $\mathrm{NO}$ can also be derived via the sequential reduction of dietary nitrate $\left(\mathrm{NO}_{3}^{-}\right)$to $\mathrm{NO}_{2}^{-}$, and further to NO. Furthermore, recent studies have demonstrated that oral $\mathrm{NO}_{3}{ }^{-}$intake, either as pure sodium $\mathrm{NO}_{3}{ }^{-}$or in the form of beetroot juice (BR), enhanced endurance exercise performance (Lansley et al., 2011a; Bond et al., 2012; Cermak et al., 2012) or exercise capacity (Bailey et al., 2009, 2010; Vanhatalo et al., 2010, 2011; Lansley et al., 2011b; Masschelein et al., 2012) in young healthy volunteers. This ergogenic effect is at least partly explained by improved mitochondrial oxygen 


\section{Puype et al.}

$\left(\mathrm{O}_{2}\right)$ efficiency (Larsen et al., 2011, 2012). $\mathrm{O}_{2}$ efficiency is particularly important in any condition that is associated with limited $\mathrm{O}_{2}$ availability, such as exercise at altitude. Moreover, increased NO-mediated vasodilation and muscle blood flow (Maiorana et al., 2003; Erzurum et al., 2007b; Umbrello et al., 2013) by facilitating myocellular $\mathrm{O}_{2}$ extraction, may also play a role in improving exercise performance in hypoxia. Interestingly, studies in our and other laboratories found lower rate of $\mathrm{O}_{2}$ consumption for a given rate of submaximal exercise (Masschelein et al., 2012; Muggeridge et al., 2014), as well as improved exercise tolerance (Vanhatalo et al., 2011; Masschelein et al., 2012) in hypoxia due to $\mathrm{NO}_{3}{ }^{-}$intake.

Against this background, it is reasonable to postulate that dietary $\mathrm{NO}_{3}{ }^{-}$supplementation may be a useful strategy to facilitate physiological adaptations to exercise training in hypoxia. Therefore, in this study, we compared the effects of 6 weeks of intermittent high-intensity endurance training in hypoxia, alone or in conjunction with dietary $\mathrm{NO}_{3}^{-}$supplementation, on maximal exercise capacity and endurance exercise performance at sea level.

\section{Methods}

\section{Subjects}

Twenty-two healthy, male subjects, aged 18-30 years volunteered to take part in the study, which was approved by the KU Leuven Ethics Committee. Subjects gave their written informed consents after they were informed of all experimental procedures and risks associated with the experiments, and underwent a medical screening. Exclusion criteria for participation were smoking, recent exposure to hypoxia, and risk factors that could compromise the subject's safety during the study. Subjects were asked to continue their normal sports and other physical activities throughout the study, and they were instructed to refrain from heavy exercise, alcohol, and caffeine-containing drinks for $48 \mathrm{~h}$ prior to the experimental sessions. Furthermore, they received a list of $\mathrm{NO}_{3}{ }^{-}-$ rich foods to be avoided during the entire study period, aiming to reduce involuntary daily $\mathrm{NO}_{3}{ }^{-}$intake. Subjects were also instructed to refrain from using antibacterial mouthwash products, which would inhibit the conversion of $\mathrm{NO}_{3}{ }^{-}$to $\mathrm{NO}_{2}{ }^{-}$by bacteria in the oral cavity (Govoni et al., 2008).

\section{Experimental protocol}

\section{Study design and experimental groups}

A randomized controlled study was performed. Subjects participated in a 6-week training program consisting of high-intensity endurance training, with a pretest before and a posttest following the intervention. One week before the pretest, a venous blood sample $(10 \mathrm{~mL})$ was taken from an arm vein into lithium heparin tubes (BD Vacutainer, Franklin Lakes, New Jersey, USA). Plasma was immediately separated by centrifugation $(2700 \mathrm{~g}$ for $10 \mathrm{~min}$ at $4{ }^{\circ} \mathrm{C}$ ) and frozen at $-80{ }^{\circ} \mathrm{C}$ for later analysis of $\left[\mathrm{NO}_{3}{ }^{-}\right]$. The subjects also performed an incremental $\mathrm{VO}_{2 \max }$ test $(60 \mathrm{~W}+20 \mathrm{~W} /$ min) on a bicycle ergometer (Avantronic Cyclus 2, Leipzig, Germany). Subsequently, they were randomly assigned to either of two experimental groups with similar distributions for age, body weight (bw), and $\mathrm{VO}_{2 \max }$ (Table 1). Both groups were enrolled in a supervised endurance training program for 6 weeks. However, one
Table 1. Subject characteristics

\begin{tabular}{lll}
\hline & CON & BR \\
\hline Age $(\mathrm{yr})$ & $21.4 \pm 0.8$ & $21.7 \pm 0.6$ \\
Weight $(\mathrm{kg})$ & $72.0 \pm 2.7$ & $72.3 \pm 4$ \\
$\mathrm{VO}_{2 \max }(\mathrm{mL} / \mathrm{min} / \mathrm{kg})$ & $60.8 \pm 1.8$ & $60.1 \pm 2.7$
\end{tabular}

Values are means \pm SEM. Subjects were enrolled in a 6-week training program in hypoxia $\left(12.5 \% \mathrm{~F}_{\mathrm{i}} 02\right)$ while receiving either $\mathrm{NO}_{3}{ }^{-}$supplementation in the form of beetroot juice $(B R, n=11)$ or a control drink (CON, $n=11$ ).

group received a control drink during this period $(\mathrm{CON}, n=11)$, while the other group received beetroot juice (BR; $n=11)$. Following the randomization, the subjects participated in two familiarization sessions with a 24-h interval. In each session, they performed a 30-min simulated time trial (TT) on the cycle ergometer. Mean power output registered in the latter session was used as the initial workload for the 30-min TT performed during both the pretest and the posttest (see later). Four days before the pretest, the subjects started the supplementation of either $\mathrm{NO}_{3}{ }^{-}(0.07 \mathrm{mmol} / \mathrm{kg}$ bw/day) in the form of BR (700 $\left.\mathrm{mg} \mathrm{NO}_{3}{ }^{-} / \mathrm{L}\right)$, or an equivalent volume of apple-blackcurrant juice (Pajottenlander, Pepingen, Belgium), which served as a control drink. The protein, carbohydrate, fiber, and vitamin content of the control drink was comparable to $\mathrm{BR}$, yet containing negligible amounts of $\mathrm{NO}_{3}{ }^{-}$. The daily dose was distributed over three equal aliquots to be ingested with breakfast, lunch, and dinner, respectively. However, during the pretest and the posttest, the full daily dose of either BR $\left(0.07 \mathrm{mmol} \mathrm{NO}_{3}{ }^{-} / \mathrm{kg}\right.$ bw, $\left.\sim 500 \mathrm{~mL}\right)$ or the control drink was administered between 2.5 and $2 \mathrm{~h}$ before the experimental session (TT) started. This supplementation was continued till the end of the posttest, which was identical to the pretest. The subjects were not informed of the exact composition of the juices and they were blinded to the true experimental hypotheses till the end of the study.

\section{Training intervention}

The subjects trained in a normobaric hypoxic facility at $12.5 \%$ $\mathrm{F}_{\mathrm{i}} \mathrm{O}_{2}$, corresponding to $\sim 4000-\mathrm{m}$ altitude. The training protocol was adapted from Vogt et al. (2001). Subjects participated for 6 weeks in five supervised training sessions per week on a bicycle ergometer. Blood lactate during the 30-min training sessions was measured at 10-min intervals, and whenever needed, workload was immediately adjusted to obtain steady-state blood lactate concentrations between 4 and $6 \mathrm{mmol} / \mathrm{L}$ (Vogt et al., 2001) while cycling at cadences between 80 and $100 \mathrm{rpm}$. Each session started with a 9-min warming up (3 min at $70 \%, 3 \mathrm{~min}$ at $80 \%$, and eventually $3 \mathrm{~min}$ at $90 \%$ of the training workload). The sessions ended with a 10-min cooling down at $50 \mathrm{~W}$. During each session, heart rate was continuously registered (Polar, Kempele, Finland), and a capillary blood sample $(5 \mu \mathrm{L})$ was collected from the earlobe at 10 and $20 \mathrm{~min}$ for control of blood lactate concentration (Lactate Pro, Arkray, Japan).

\section{Pretest and posttest}

The pretest and the posttest each involved two experimental sessions interspersed by a 2-day rest interval. On the evening before each test day, the subjects received a standardized dinner (1000 kcal: $60 \mathrm{E} \%$ carbohydrates, $27 \mathrm{E} \%$ fat, $13 \mathrm{E} \%$ protein). In the first experimental session, the subjects reported to the laboratory between 7:00 and 10:30 h after a 10- to 12-h overnight fast. On arrival, they received a standardized carbohydrate-rich breakfast (710 kcal: $84 \mathrm{E} \%$ carbohydrates, $7 \mathrm{E} \%$ fat, $9 \mathrm{E} \%$ protein) together 


\section{Nitrate intake and hypoxic training}

with $\mathrm{BR}\left(0.07 \mathrm{mmol} \mathrm{NO}_{3}{ }^{-} / \mathrm{kg}\right.$ bw) or CON. After a $\sim 2$-h rest, a venous blood sample $(10 \mathrm{~mL})$ was taken from an arm vein into lithium heparin tubes. Furthermore, a percutaneous needle biopsy was taken from the left $\mathrm{m}$. vastus lateralis under local anesthetic (2-3 mL lidocaine, subcutaneously) through an incision in the skin. Following the biopsy, the subjects started the 30-min TT session on the cycle ergometer. After a 10-min warming up (5 min at $100 \mathrm{~W}$ plus $5 \mathrm{~min}$ at $150 \mathrm{~W})$ the TT was started $\left(\mathrm{t}_{0}-\mathrm{t}_{5}\right)$ at $198 \pm 4 \mathrm{~W}$, which is the individual workload obtained from the second familiarization session. From $t_{5}$ to $t_{25}$, subjects could adjust the workload at 5-min intervals according to their subjective perception of fatigue. From $t_{25}$ to $t_{30}, 1$-min adjustments were allowed so as to reach a point of full exhaustion at the end of the TT. Because workload was set identical between the pretest and the posttest from $t_{0}$ to $t_{5}$, values measured in this time window were not further considered in the statistical analyses (see later). At $t_{0}$, $\mathrm{t}_{20}$, and $\mathrm{t}_{30}$, a 5- $\mu \mathrm{L}$ blood sample was taken from the earlobe for lactate determination. Arterial $\mathrm{O}_{2}$ saturation $\left(\% \mathrm{SpO}_{2}\right)$ was measured by pulsoxymetry using a sensor just above the left eyebrow (Nellcor N-600-x, Oxismart, Mallinckrodt, St. Louis, Missouri, USA). Furthermore, heart rate and power output were continuously measured but were hidden to the subjects. At the end of the TT, a second muscle biopsy was taken through the same incision as the preexercise biopsy. Two days later, the subjects returned to the laboratory between 7:00 and 10:30 h after a 10- to 12-h overnight fast to perform a $\mathrm{VO}_{2 \max }$ test. Initial workload was set at $60 \mathrm{~W}$ and was increased by $35 \mathrm{~W} / 3$ min until volitional exhaustion or failure to maintain cadence $>65 \mathrm{rpm}$. During the test heart rate, $\% \mathrm{SpO}_{2}$ and pulmonary gas exchange parameters (Cortex ${ }^{\circledR}$ Metalyzer II, Leipzig, Germany) were continuously measured and blood $(5 \mu \mathrm{L})$ was sampled from the earlobe for lactate assay at the end of each stage. Following the 6-week intervention period, subjects abstained from training for 3 days, where after they participated in the posttest, which was identical to the pretest and on the same days of the week. The BR and CON were supplied till the last day of the posttest.

\section{Analysis of blood and muscle samples}

\section{Plasma nitrate}

Blood sampling for $\mathrm{NO}_{3}{ }^{-}$assay was only included in a later stage of the study, yielding a reduced number of observations ( $\mathrm{CON}, n=7$; $\mathrm{BR}, n=6$ ). Following sampling, the plasma was immediately separated by centrifugation and stored at $-80{ }^{\circ} \mathrm{C}$ for later analysis of $\left[\mathrm{NO}_{3}{ }^{-}\right]$by a fluorometric assay using 2,3-diaminonaphthalene (Nussler et al., 2006).

\section{Muscle biochemistry}

Part of the muscle samples was immediately frozen in liquid nitrogen and stored at $-80{ }^{\circ} \mathrm{C}$ till later analysis. Muscle glycogen content was measured as glucose residues after acid hydrolysis using a standard enzymatic fluorometric assay (Lowry \& Passoneau, 1972).

\section{Western blotting}

Frozen muscle tissue $(\sim 20 \mathrm{mg})$ was homogenized $3 \times 5 \mathrm{~s}$ with a Polytron mixer in ice-cold buffer $(1: 10, \mathrm{w} / \mathrm{v})$ [50-mM Tris- $\mathrm{HCl}$ pH 7.0, 270-mM sucrose, 5-mM EGTA, 1-mM EDTA, 1-mM sodium orthovanadate, $50-\mathrm{mM}$ glycerophosphate, 5 -mM sodium pyrophosphate, 50-mM sodium fluoride, 1-mM DTT, $0.1 \%$ Triton-X 100, and a complete protease inhibitor tablet (Roche Applied Science, Vilvoorde, Belgium)]. Homogenates were then centrifuged at $10000 \mathrm{~g}$ for $10 \mathrm{~min}$ at $4{ }^{\circ} \mathrm{C}$. The supernatant was collected and immediately stored at $-80^{\circ} \mathrm{C}$. The protein concen- tration was measured using the DC protein assay kit (Bio-Rad Laboratories, Nazareth, Belgium). Thirty to eighty micrograms of proteins were separated by SDS-PAGE (10\% gel) and transferred to PVDF membranes. Subsequently, membranes were blocked with 5\% nonfat milk for $1 \mathrm{~h}$ and afterwards incubated overnight $\left(4{ }^{\circ} \mathrm{C}\right)$ with the following antibodies $(1: 1000$, Cell Signaling, Leiden, The Netherlands): phospho-AMP-activated protein kinase (AMPK) and total AMPK. Horseradish peroxidase-conjugated antirabbit secondary antibody (1:5000) (Sigma-Aldrich, Bornem, Belgium) was used for chemiluminescent detection of the proteins. Membranes were scanned and quantified with Genesnap and Genetools Softwares (Syngene, Cambridge, UK), respectively (Deldicque et al., 2010). Results were expressed relative to a standard sample that was run together with the samples to allow comparisons between membranes, and phospho-AMPK data are reported relative to AMPK total. All values were divided by the mean value of the first biopsy sample (pretest) from the respective condition

\section{RNA extraction, reverse transcription and real-time qPCR analysis}

Total RNA was extracted using TRIzol (Invitrogen, Vilvoorde, Belgium) from 20 to $25 \mathrm{mg}$ of frozen muscle tissue. RNA quality and quantity were assessed by spectrophotometry with a Nanodrop (Thermo Scientific, Erembodegem, Belgium). One microgram of RNA was reverse transcribed using the High Capacity cDNA Reverse Transcription Kit (Applied Biosystems, Gent, Belgium) according to manufacturer's instructions. A SYBR Green-based Master Mix (Applied Biosystems) was used for realtime polymerase chain reaction (PCR) analyses using the ABI PRISM 7300 (Applied Biosystems). Real-time PCR primers were designed for hypoxia inducible factor- $1 \alpha$ (HIF- $1 \alpha$; primer sequence: forward, GCC CCA GAT TCA GGA TCA GA; reverse TGG GAC TAT TAG GCT CAG GTG AAC). Thermal cycling conditions consisted of 40 three-step cycles including denaturation of $30 \mathrm{~s}$ at $95{ }^{\circ} \mathrm{C}$, annealing of $30 \mathrm{~s}$ at $58{ }^{\circ} \mathrm{C}$, and extension of $30 \mathrm{~s}$ at $72{ }^{\circ} \mathrm{C}$. All reactions were performed in triplicate. To compensate for variations in input RNA amounts and efficiency of reverse transcription, ribosomal protein L4 (RPL4), RPL19, and beta-2microglobulin ( $\beta-2-\mathrm{MG})$ mRNA were quantified and results were normalized to these values. These genes were chosen out of five normalization genes using the GeNorm applet according to the guidelines and theoretical framework described elsewhere (Vandesompele et al., 2002). All values were divided by the mean value of the first biopsy sample (pretest) from the respective condition.

\section{Statistical analyses}

The effect of the intervention was evaluated using repeatedmeasures analysis of variance (ANOVA). Two-way ANOVA was performed to compare the effects of the training in hypoxia in the absence or presence of daily $\mathrm{NO}_{3}{ }^{-}$intake (CON vs BR). A planned contrast analysis was used for post hoc comparisons when appropriate. Contrast analysis was also used to evaluate specific preplanned comparisons. Also, the $95 \%$ confidence intervals [mean $\pm 1.96 \times$ standard error of mean $(\mathrm{SEM})]$ of the relative change in performance parameters were calculated. A probability level $(P) \leq 0.05$ was considered statistically significant. All data are expressed as means \pm SEM.

\section{Results}

Training intensity (Table 2)

Mean power output, heart rate, and blood lactate were similar between CON and BR throughout the training 


\section{Puype et al.}

Table 2. Training intensity at the start and at the end of the training period

\begin{tabular}{lcc}
\hline & Week 1 & Week 6 \\
\hline $\begin{array}{l}\text { Mean power output (Watt) } \\
\text { CON }\end{array}$ & $126 \pm 6$ & $134 \pm 5^{*}$ \\
BR & $139 \pm 6$ & $147 \pm 5^{\star}$ \\
Heart rate (bpm) & $165 \pm 2$ & $165 \pm 2$ \\
CON & $160 \pm 2$ & $160 \pm 2$ \\
BR & & \\
$\%$ HR max & $83 \pm 1.0$ & $83 \pm 0.8$ \\
CON & $86 \pm 1.5$ & $86 \pm 1.2$ \\
BR & & \\
Blood lactate $(\mathrm{mmol} / \mathrm{L})$ & $5.68 \pm 0.19$ & $5.75 \pm 0.18$ \\
CON & $5.59 \pm 0.27$ & $5.23 \pm 0.14$ \\
BR &
\end{tabular}

${ }^{*} P<0.05$ vs week 1 .

Values are means \pm SEM. Subjects were enrolled in a 6 -week training program in hypoxia $\left(12.5 \% \mathrm{~F}_{\mathrm{O}} 02\right)$ while receiving either $\mathrm{NO}_{3}{ }^{-}$supplementation in the form of beetroot juice (BR, $n=11)$ or a control drink (CON, $n=11)$. Mean power output, heart rate $(\mathrm{HR})$, and blood lactate were measured after $20 \mathrm{~min}$ in the 30 -min training bouts during week 1 and week 6 of the training period. Percent HR max is expressed relative to the corresponding maximal HR measured in the pretest (Table 4).

period. Mean power outputs during training increased by $\sim 6 \%$ in both groups from week 1 to week $6(P<0.05)$.

\section{TT performance (Table 3)}

In the pretest, there were no significant differences between the groups either for mean power output, or for heart rate or blood lactate concentration during the TT. However, $\% \mathrm{SpO}_{2}$ was slightly higher in $\mathrm{BR}$ than in $\mathrm{CON}$ $(P<0.05)$. From the pretest to the posttest, mean power

Table 3. Effects of beetroot juice in conjunction with high-intensity endurance training in the time trial

\begin{tabular}{lllc}
\hline & Pretest & Posttest & $\Delta(\mathrm{Cl})$ \\
\hline Mean power output(Watt) & & & \\
CON & $203 \pm 14$ & $235 \pm 14^{*}$ & $32(28 ; 36)$ \\
BR & $215 \pm 8$ & $252 \pm 9^{*}$ & $37(28 ; 45)$ \\
Mean Sp0 $(\%)$ & & & \\
$\quad$ CON & $96.6 \pm 0.4$ & $97.2 \pm 0.2$ & $0.5(0.1 ; 1.0)$ \\
BR & $98.1 \pm 0.2^{\dagger}$ & $97.8 \pm 0.3$ & $-0.2(-0.9 ; 0.4)$ \\
Mean HR (bpm) & $182 \pm 3$ & $183 \pm 4$ & $0.7(-5 ; 7)$ \\
CON & $177 \pm 4$ & $176 \pm 4$ & $-0.3(-3 ; 3)$ \\
BR & & & \\
\%R max & $92 \pm 1.0$ & $93 \pm 1.6$ & $0.9(-2.9 ; 4.8)$ \\
CON & $95 \pm 1.4$ & $95 \pm 1.0$ & $-0.1(-1.6 ; 1.4)$ \\
BR & & & \\
Lactate at 20 min (mmol/L) & $6.8 \pm 0.5$ & $7.2 \pm 0.6$ & $0.4(-0.5 ; 1.2)$ \\
CON & $5.2 \pm 0.7$ & $5.6 \pm 0.7$ & $0.4(-1.0 ; 1.8)$ \\
BR & & & \\
Lactate at 30 min (mmol/L) & $8.5 \pm 0.6$ & $9.5 \pm 0.6$ & $1.0(-0.03 ; 2.0)$ \\
$\quad$ CON & $8.0 \pm 0.5$ & $9.3 \pm 0.5$ & $1.3(-0.4 ; 3.0)$ \\
BR & & & \\
\hline
\end{tabular}

${ }^{\star} P<0.05$ vs pretest; ${ }^{\dagger} P<0.05$ vs CON.

Values are means \pm SEM, except for $\Delta \mathrm{S}$ where mean and $95 \%$ confidence intervals (Cls) are given. Subjects were enrolled in a 6-week training program in hypoxia $\left(12.5 \% \mathrm{~F}_{\mathrm{i}} 02\right)$ while receiving either $\mathrm{NO}_{3}{ }^{-}$supplementation in the form of beetroot juice (BR, $n=11$ ) or a control drink (CON, $n=11$ ). In both the pretest and the posttest, the subjects performed a 30-min simulated time trial on a cycle ergometer. HR, heart rate; \% HR max is expressed relative to the corresponding maximal HR measured in the pretest (Table 4). output during the TT increased to the same extent $(\sim 17 \%)$ in $\mathrm{CON}$ and $\mathrm{BR}(P<0.05)$. Also, $\% \mathrm{SpO}_{2}$, heart rates, as well as blood lactate levels in the posttest, were similar between the groups.

\section{Incremental exercise test (Table 4)}

Irrespective of the experimental condition, the training intervention increased time to exhaustion from $\sim 22.5 \mathrm{~min}$ in the pretest to $\sim 25.5 \mathrm{~min}$ in the posttest $[P<0.05 \mathrm{vs}$ pretest; non-significant (n.s.) between groups]. $\mathrm{VO}_{2 \max }$ increased by $\sim 5 \%$ in $\mathrm{CON}$ vs $\sim 9 \%$ in $\mathrm{BR}(P<0.05$ vs pretest; n.s. between groups). Peak heart rates were similar between the pretest and the posttest, yet were slightly lower in BR than in CON $(P<0.05)$. Furthermore, blood lactate and respiratory exchange ratio at peak exercise were similar between the pretest and the posttest in both groups, yet in $\mathrm{BR}$, peak blood lactate was slightly lower in the posttest than in the pretest $(P<0.05)$. Furthermore, the training increased power output at the 4-mM lactate threshold (LT4) by $\sim 13 \%$ in CON vs $\sim 16 \%$ in $\mathrm{BR}(P<0.05$ vs pretest; $n$.s. between groups $)$. Irrespective of the experimental condition, $\% \mathrm{SpO}_{2}$ values at peak exercise (data not shown) were in the range of $94-96 \%$ in both the pretest and the posttest.

\section{Muscle glycogen, phospho-AMPK and HIF-1 $\alpha$ mRNA expression (Table 5)}

Muscle biopsies were taken before and immediately after the 30-min TT in the pretest and the posttest. There were no significant differences between the groups either

Table 4. Effects of beetroot juice in conjunction with high-intensity endurance training during the incremental $\mathrm{VO}_{2 \max }$ test

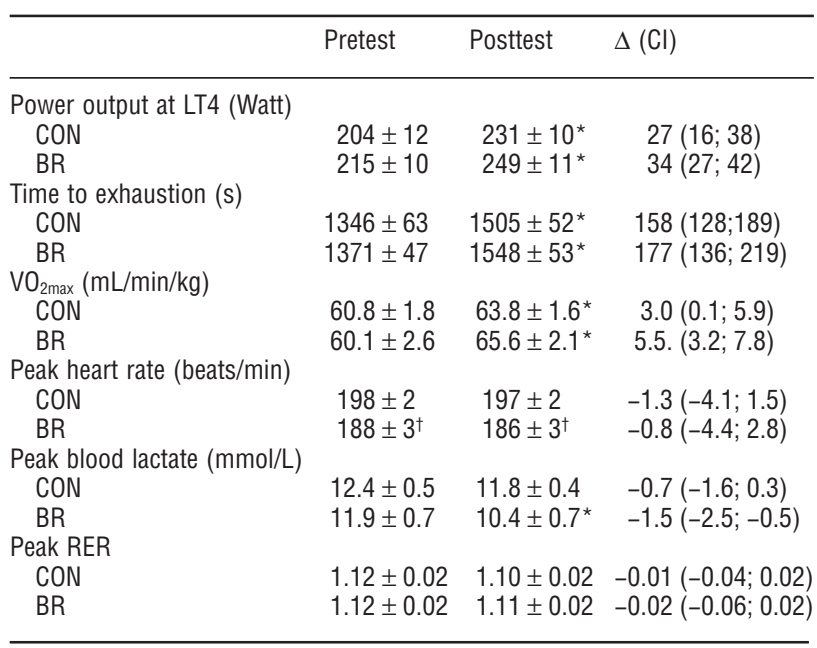

${ }^{\star} P<0.05$ vs pretest; ${ }^{\dagger} P<0.05$ vs CON.

Values are means \pm SEM, except for $\Delta$ s where mean and $95 \%$ confidence intervals (Cls) are given. Subjects were enrolled in a 6-week training program in hypoxia $\left(12.5 \% \mathrm{~F}_{\mathrm{i}} \mathrm{O} 2\right)$ while receiving either $\mathrm{NO}_{3}{ }^{-}$supplementation in the form of beetroot juice (BR, $n=11)$ or a control drink (CON, $n=11$ ). In both the pretest and the posttest, the subjects performed a maximal incremental exercise test on a cycle ergometer. RER, respiratory exchange ratio. 
Nitrate intake and hypoxic training

Table 5. Effects of beetroot supplementation in conjunction with high-intensity endurance training on muscle biochemistry before and after a time trial

\begin{tabular}{|c|c|c|c|c|}
\hline & \multicolumn{2}{|l|}{ CON } & \multicolumn{2}{|l|}{$\mathrm{BR}$} \\
\hline & Before & After & Before & After \\
\hline \multicolumn{5}{|c|}{ Glycogen content } \\
\hline Pretest & $142 \pm 12$ & $73 \pm 8^{\dagger}$ & $156 \pm 13$ & $94 \pm 13^{\dagger}$ \\
\hline Posttest & $185 \pm 17^{\star}$ & $103 \pm 11^{* \dagger}$ & $185 \pm 10^{*}$ & $125 \pm 11^{* \dagger}$ \\
\hline \multicolumn{5}{|c|}{ HIF1- $\alpha$ mRNA } \\
\hline Pretest & $1.00 \pm 0.17$ & $1.08 \pm 0.08$ & $1.00 \pm 0.08$ & $1.08 \pm 0.15$ \\
\hline Posttest & $1.44 \pm 0.08$ & $1.02 \pm 0.14$ & $1.28 \pm 0.14$ & $0.95 \pm 0.14$ \\
\hline \multicolumn{5}{|c|}{ P-AMPK/Total AMPK } \\
\hline Pretest & $1.00 \pm 0.12$ & $1.40 \pm 0.13$ & $1.00 \pm 0.16$ & $1.32 \pm 0.18$ \\
\hline Posttest & $0.93 \pm 0.13$ & $1.27 \pm 0.11$ & $1.11 \pm 0.13$ & $1.40 \pm 0.18$ \\
\hline
\end{tabular}

${ }^{*} P<0.05$ vs pretest; ${ }^{\dagger} P<0.05$ vs before.

Values are means \pm SEM. Subjects were enrolled in a 6-week training program in hypoxia $\left(12.5 \% \mathrm{~F}_{i} 02\right)$ while receiving either $\mathrm{NO}_{3}{ }^{-}$supplementation in the form of beetroot juice (BR, $n=11$ ) or a control drink (CON, $n=11$ ). In both the pretest and the posttest, a needle biopsy was taken from $\mathrm{m}$. vastus lateralis before and after a 30-min simulated time trial (TT) on a cycling ergometer. HIF1- $\alpha$, hypoxia inducible factor 1-alpha; AMPK, adenosine monophosphateactivated protein kinase. See Methods for more details.

for HIF- $1 \alpha$ mRNA content or for the ratio phosphoAMPK/AMPK total in either the pretest or the posttest. Compared with the pretest, preexercise muscle glycogen contents were increased in the posttest $(P<0.05)$, yet there were no differences between the groups at any time. Net glycogen breakdown during the TT was also similar between the pretest and the posttest in both groups.

\section{Plasma nitrate (Fig. 1)}

Baseline plasma $\mathrm{NO}_{3}^{-}$concentrations were similar between groups and were constant throughout the study in CON. Compared with $\mathrm{CON}$, the administration of $\mathrm{BR}$ in the pretest increased plasma $\left[\mathrm{NO}_{3}{ }^{-}\right] \sim$ sixfold $(P<0.05)$, with no further increase in the posttest.

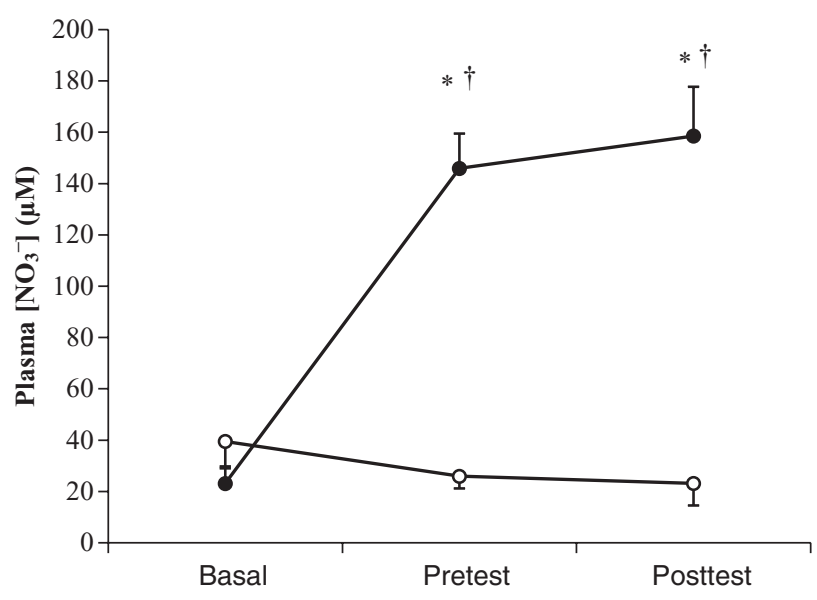

Fig. 1. Effect of beetroot juice on plasma nitrate concentration. Values are means \pm SEM for plasma nitrate $(\mu \mathrm{M})$ before (basal), after 4 days (pretest) and 8 weeks (posttest) of beetroot supplementation $(0)$ or a control drink $(\bigcirc)$. Between the pretest and the posttest, the subjects were enrolled in a 6-week training program in hypoxia $\left(12.5 \% \mathrm{~F}_{\mathrm{i}} 02\right)$. See Methods for more details. $* P<0.05$ vs basal; ${ }^{\dagger} P<0.05$ vs $\mathrm{CON}$.

\section{Discussion}

The hypothesis driving this study was that dietary $\mathrm{NO}_{3}^{-}$ supplementation could enhance the effects of IHT on endurance exercise performance. For oral $\mathrm{NO}_{3}^{-}$, intake stimulates $\mathrm{NO}$ production on the one hand and NO conceivably plays a role in adaptation to both endurance training and hypoxia on the other hand (Kingwell et al., 1997; Manukhina et al., 2006; Levett et al., 2011; Limberg et al., 2011). However, against our hypothesis, the data shown in this manuscript indicate that chronic dietary $\mathrm{NO}_{3}{ }^{-}$supplementation in the form of BR adds neither to the effects of IHT to increase $\mathrm{VO}_{2 \max }$ nor does it enhances power output at the anaerobic threshold or TT performance at sea level.

We enrolled moderately trained healthy volunteers in a 6-week high-intensity endurance training program involving five weekly sessions of cycling training (30 $\mathrm{min}$ ) at a workload corresponding to $4-6 \mathrm{mmol} / \mathrm{L}$ circulating blood lactate. Such training program in hypoxia $(\sim 4000 \mathrm{~m})$, compared with similar training in normoxia, was previously demonstrated to stimulate some beneficial physiological adaptations in muscles, yet failed to significantly enhance functional capacity at sea level (Vogt et al., 2001). An identical training program in the current study increased $\mathrm{VO}_{2 \max }$ by $5-9 \%$, and enhanced power output at LT4 and during the 30 -min TT by $\sim 15 \%$.

We postulated that daily supplementation of $\mathrm{NO}_{3}{ }^{-}$in the form of BR could enhance the aforementioned effects of hypoxic training on performance during exercise at sea level. In this regard, it is important to note that we started the BR administration already 4 days before the pretest with the express purpose of eliminating the well-documented acute ergogenic effects of $\mathrm{NO}_{3}{ }^{-}$ supplementation in endurance exercise performance (Hoon et al., 2013). Thus, $\mathrm{NO}_{3}^{-}$intake $(0.07 \mathrm{mmol} / \mathrm{kg}$ bw) $\sim 2.5 \mathrm{~h}$ before the pretest increased plasma $\mathrm{NO}_{3}{ }^{-}$ 


\section{Puype et al.}

concentration $\sim$ sixfold, which is in line with earlier observations of Wylie et al. (Wylie et al., 2013). Furthermore, the daily extra $\mathrm{NO}_{3}{ }^{-}$intake during the training period did not alter the plasma $\mathrm{NO}_{3}^{-}$response to the acute BR bolus in the posttest. Against this background, differences between the pretest and posttest reflect the effect of chronic $\mathrm{NO}_{3}{ }^{-}$intake in $\mathrm{BR}$ vs $\mathrm{CON}$, which did not receive the daily $\mathrm{NO}_{3}{ }^{-}$supplements. However, $\mathrm{BR}$ stimulated neither the training-induced increments in $\mathrm{VO}_{2 \max }$, nor enhanced the gain in power output at LT4 or during the TT from the pretest to the posttest. In fact, for none of the variables measured in either the TT or the incremental $\mathrm{VO}_{2 \max }$ test, we found a significant difference between BR and CON. This clearly indicates that in the conditions of the current study, exogenous $\mathrm{NO}_{3}{ }^{-}$ supplementation failed to augment the effect of hypoxic training to stimulate functional capacity in endurance exercise at sea level.

Several mechanisms may explain these "negative" observations. First, exercise training per se in healthy individuals readily elevates NO bioavailability via increased NOS enzyme expression and activity (Kingwell et al., 1997; Kingwell, 2000; Manukhina et al., 2006). Accordingly, Kingwell et al. (1997) nicely demonstrated that just 4 weeks of cycling training markedly reduced $\mathrm{NO}_{3}{ }^{-}$and $\mathrm{NO}_{2}{ }^{-}$consumption by the human forearm, which is consistent with increased NO production through the NOS pathway. Given the elevated capacity for NO production via endogenous pathways due to training, it is reasonable to assume that any additional stimulation of $\mathrm{NO}$ production from exogenous $\mathrm{NO}_{3}{ }^{-}$may be redundant. Such conclusion is corroborated by the finding that the effect of $\mathrm{NO}_{3}{ }^{-}$supplementation to improve $\mathrm{O}_{2}$ efficiency and performance in endurance exercise is much more explicit in normal healthy volunteers than in highly endurance-trained individuals (Christensen et al., 2013; Hoon et al., 2013).

Second, an obvious way to stimulate training adaptation by $\mathrm{NO}_{3}{ }^{-}$administration would be to enhance training intensity by the administration of a high $\mathrm{NO}_{3}{ }^{-}$dose ( $\sim 5-8$ mmol bolus) $2-3 \mathrm{~h}$ before the start of the training sessions. It is now well established that acute $\mathrm{NO}_{3}{ }^{-}$intake can enhance $\mathrm{O}_{2}$ efficiency during exercise in hypoxia and thereby also improve exercise tolerance (Vanhatalo et al., 2011; Masschelein et al., 2012; Muggeridge et al., 2014). We previously also found lower circulating blood lactate concentration due to $\mathrm{NO}_{3}{ }^{-}$intake during submaximal constant-load exercise in hypoxia (Masschelein et al., 2012). Furthermore, it has been well documented that $\mathrm{NO}_{3}{ }^{-}$supplementation reduces muscle metabolic perturbation for a given submaximal exercise intensity in hypoxia (Vanhatalo et al., 2011). However, this does not necessarily imply that $\mathrm{NO}_{3}{ }^{-}$supplementation fully eliminates hypoxic stress during exercise at (simulated) altitude. Rather, it may permit a more efficient $\mathrm{O}_{2}$ utilization against the face of a lower degree of hypoxic stress. As a result, higher training workloads may be performed, which in turn is conceivably associated with recruitment of a higher fraction of fast-twitch motor units that are otherwise "blind" to the hypoxic training stimulus. Therefore, $\mathrm{NO}_{3}{ }^{-}$intake might be a useful strategy to enhance training adaptations by facilitating higher training intensities during IHT sessions, indeed. Nevertheless, one should also consider the possibility that $\mathrm{NO}_{3}^{-}$, by increasing $\mathrm{O}_{2}$ efficiency, may reduce the degree of hypoxia occuring in muscle cells during IHT, and thereby inhibits additional training adaptations. The $\mathrm{NO}_{3}{ }^{-}$administration protocol used in the current study probably was inadequate to stimulate performance in the training sessions. The total daily $\mathrm{NO}_{3}{ }^{-}$dose was distributed over three aliquots per day ( $\sim 1.7 \mathrm{mmol}$ at breakfast, lunch, dinner), and training sessions were scheduled between 2 and $4 \mathrm{~h}$ following either breakfast or lunch. Such dosage protocol results in too low circulating peak plasma $\mathrm{NO}_{2}{ }^{-}$levels to enhance $\mathrm{O}_{2}$ efficiency during exercise (Wylie et al., 2013), and thereby improve exercise tolerance in hypoxia. Unfortunately, we could not measure plasma $\mathrm{NO}_{2}{ }^{-}$. Earlier studies have shown that circulating plasma $\left[\mathrm{NO}_{2}{ }^{-}\right]$increases between 1 and 15 days of $\mathrm{NO}_{3}{ }^{-}$administration at a dose of $5.2 \mathrm{mmol} /$ day (Vanhatalo et al., 2010). However, whether this finding can be extrapolated to even longer periods of oral $\mathrm{NO}_{3}{ }^{-}$supplementation remains to be established. In addition, as indicated above, the $\mathrm{NO}_{3}{ }^{-}$administration protocol used was successful to chronically increasing plasma $\mathrm{NO}_{3}^{-}$concentration, indeed. However, it is difficult to predict, on an individual level, whether this increase in plasma $\left[\mathrm{NO}_{3}{ }^{-}\right]$was paralleled by elevated plasma $\left[\mathrm{NO}_{2}^{-}\right]$, which definitely is the more direct parameter to predict $\mathrm{NO}$ availability and biological activity (Dejam et al., 2004).

In the current study during the intervention period, we administered $\quad 300-400 \mathrm{mg} \quad(0.07 \mathrm{mmol} / \mathrm{kg} \quad$ bw $)$ of molecular $\mathrm{NO}_{3}{ }^{-}$per day. This intake rate is substantially higher than the mean of $\sim 90 \mathrm{mg}$ daily in an average Western population and within the range of vegetarian diets delivering up to $1500 \mathrm{mg}$ of $\mathrm{NO}_{3}{ }^{-}$per day (Hill et al., 1996; Hord et al., 2009; Mitek et al., 2013). Based on this comparison, it is probably reasonable to conclude that increasing daily $\mathrm{NO}_{3}{ }^{-}$intake just by intermittent $\mathrm{NO}_{3}{ }^{-}$ intake via meals, snacks, and drinks is not an adequate strategy to enhance training adaptations in hypoxia. Against the prevailing opinion to date, emerging evidence indicates that diets rich in $\mathrm{NO}_{3}{ }^{-}$via fruits and vegetables do not increase the prevalence of stomach cancer. Furthermore, a series of recent studies have shown beneficial effects of dietary $\mathrm{NO}_{3}{ }^{-}$intake in cardiovascular and metabolic disease. Still, long-term high-dose $\mathrm{NO}_{3}{ }^{-}$ supplementation should still be approached with caution till further scientific research on the safety of high-dose $\mathrm{NO}_{3}{ }^{-}$boluses typically used by athletes has been done (Bryan et al., 2012; Weitzberg \& Lundberg, 2013).

It is well documented that AMPK probably plays an important role in muscular metabolic and structural adaptations to exercise training (Richter \& Ruderman, 
2009). Furthermore, exercise effects on muscle not only depend on exercise intensity but also on the degree of intramyocellular $\mathrm{O}_{2}$ desaturation (Geiser et al., 2001;Hoppeler \& Vogt, 2001). Therefore, it is believed that activation of HIF-1 is necessary for training adaptation by induction of "hypoxia-sensitive genes" such as vascular endothelial growth factor or glycolytic enzymes, as well as other metabolic proteins (Hoppeler et al., 2008). The 30-min TT per se tended to increase AMPK phosphorylation status both in the pretest and the posttest, yet there was no difference between the experimental groups at any time, either for AMPK total protein content or for the phosphorylated fraction. By analogy, irrespective of the experimental condition, HIF- $1 \alpha$ mRNA contents were similar between the pretest and the posttest both before and after exercise. Thus, consistent with the absence of beneficial effects on functional capacity, $\mathrm{NO}_{3}^{-}$intake did not alter the AMPK and HIF- $1 \alpha$ responses to the 6 -week training period. Because glycogen breakdown for a given rate of muscle contractions is exaggerated by hypoxia (Parolin et al., 2000), we decided also to assess the effect of the training interventions on net glycogen breakdown during the TT. Training expectedly increased basal muscle glycogen content in both CON and BR, but exercise-induced net glycogen breakdown was similar between groups in both the pretest and the posttest.

In conclusion, the present study clearly demonstrates that long-term low-dose dietary $\mathrm{NO}_{3}^{-}$supplementation does not enhance the effects of intermittent endurance training in hypoxia on either the anaerobic threshold, $\mathrm{VO}_{2 \max }$, or endurance exercise performance at sea level.

\section{Perspectives}

The hypothesis driving this study was that daily $\mathrm{NO}_{3}^{-}$ supplementation could possibly enhance the effects of hypoxic training on sea-level performance. However, one could also argue that suppression of muscular $\mathrm{O}_{2}$ deficiency during contractions by improved $\mathrm{O}_{2}$ efficiency due to $\mathrm{NO}_{3}^{-}$intake, in fact, might inhibit training adaptation. Yet we found similar training adaptations to hypoxic training, irrespective of whether the training was done alone or in conjunction with daily $\mathrm{NO}_{3}{ }^{-}$intake. Still, our data do not exclude that higher daily doses of $\mathrm{NO}_{3}{ }^{-}$, probably best to be administered as a bolus $2-3 \mathrm{~h}$ prior to the training sessions, or just longer periods of $\mathrm{NO}_{3}{ }^{-}$intake, could still affect training adaptations. It is recommended that such long-term studies also address the impact of the $\mathrm{NO}_{3}{ }^{-}$administration protocol on primary health parameters.

Key words: Nitric oxide, altitude, high-intensity endurance training, aerobic capacity.

\section{Acknowledgements}

This work was supported by a grant from the Flanders Fund for Scientific Research (FWO-Vlaanderen, Grant \# G.0706.09N) and by the Onderzoeksraad KU Leuven (grant \# OT/09/033). The beetroot and apple/blackcurrant juices needed for this study were kindly donated by Pajottenlander (Pepingen, Belgium). The authors are thankful to the subjects for their participation and adherence to the training protocol. We thank Karen Van Proeyen for her support in the organization of the study.

\section{References}

Bailey SJ, Winyard P, Vanhatalo A, Blackwell JR, DiMenna FJ, Wilkerson DP, Tarr J, Benjamin N, Jones AM. Dietary nitrate supplementation reduces the $\mathrm{O} 2$ cost of low-intensity exercise and enhances tolerance to high-intensity exercise in humans. J Appl Physiol 2009: 107: 1144-1155.

Bailey SJ, Fulford J, Vanhatalo A, Winyard PG, Blackwell JR, DiMenna FJ, Wilkerson DP, Benjamin N, Jones AM. Dietary nitrate supplementation enhances muscle contractile efficiency during knee-extensor exercise in humans. J Appl Physiol 2010: 109: 135-148.

Bond H, Morton L, Braakhuis AJ. Dietary nitrate supplementation improves rowing performance in well-trained rowers. Int J Sport Nutr Exerc Metab 2012: 22: 251-256.

Bonetti DL, Hopkins WG. Sea-level exercise performance following adaptation to hypoxia: a meta-analysis. Sports Med 2009: 39: 107-127.
Bryan NS, Alexander DD, Coughlin JR, Milkowski AL, Boffetta P. Ingested nitrate and nitrite and stomach cancer risk: an updated review. Food Chem Toxicol 2012: 50: 3646-3665.

Cermak NM, Gibala MJ, van Loon LJ. Nitrate supplementation's improvement of $10-\mathrm{km}$ time-trial performance in trained cyclists. Int J Sport Nutr Exerc Metab 2012: 22: 64-71.

Christensen PM, Nyberg M, Bangsbo J. Influence of nitrate supplementation on $\mathrm{VO}(2)$ kinetics and endurance of elite cyclists. Scand J Med Sci Sports 2013: 23: e21-e31.

Dejam A, Hunter CJ, Schechter AN, Gladwin MT. Emerging role of nitrite in human biology. Blood Cells Mol Dis 2004: 32: 423-429.

Deldicque L, De Bock K, Maris M, Ramaekers M, Nielens H, Francaux M, Hespel P. Increased p70s6k phosphorylation during intake of a protein-carbohydrate drink following resistance exercise in the fasted state.
Eur J Appl Physiol 2010: 108: 791-800.

Erzurum SC, Ghosh S, Janocha AJ, Xu W, Bauer S, Bryan NS, Tejero J, Hemann C, Hille R, Stuehr DJ, Feelisch M, Beall CM. Higher blood flow and circulating NO products offset high-altitude hypoxia among Tibetans. Proc Natl Acad Sci U S A 2007a: 104: 17593-17598.

Erzurum SC, Ghosh S, Janocha AJ, Xu W, Bauer S, Bryan NS, Tejero J, Hemann C, Hille R, Stuehr DJ, Feelisch M, Beall CM. Higher blood flow and circulating NO products offset high-altitude hypoxia among Tibetans. Proc Natl Acad Sci U S A 2007b: 104: 17593-17598.

Geiser J, Vogt M, Billeter R, Zuleger C, Belforti F, Hoppeler H. Training high-living low: changes of aerobic performance and muscle structure with training at simulated altitude. Int J Sports Med 2001: 22: 579-585. 


\section{Puype et al.}

Govoni M, Jansson EA, Weitzberg E, Lundberg JO. The increase in plasma nitrite after a dietary nitrate load is markedly attenuated by an antibacterial mouthwash. Nitric Oxide 2008: 19: 333-337.

Hill MJ, Elliott P, Joossens JV, Packer PJ, Kesteloot H, Nichols R, Leach S, Dyer A, Stamler R, Stamler J. Twenty-four hour urinary nitrate excretion in 48 populations from 30 countries: an ECP-INTERSALT collaborative study. Int J Epidemiol 1996: 25: 505-512.

Hoon MW, Johnson NA, Chapman PG, Burke LB. The effect of nitrate supplementation on exercise performance in healthy individuals: a systematic review and meta-analysis. Int J Sport Nutr Exerc Metab 2013.

Hoppeler H, Vogt M. Muscle tissue adaptations to hypoxia. J Exp Biol 2001: 204: 3133-3139.

Hoppeler H, Klossner S, Vogt M. Training in hypoxia and its effects on skeletal muscle tissue. Scand J Med Sci Sports 2008: 18 (Suppl. 1): 38-49.

Hord NG, Tang Y, Bryan NS. Food sources of nitrates and nitrites: the physiologic context for potential health benefits. Am J Clin Nutr 2009: 90: $1-10$.

Kingwell BA. Nitric oxide-mediated metabolic regulation during exercise: effects of training in health and cardiovascular disease. FASEB J 2000: 14: 1685-1696.

Kingwell BA, Sherrard B, Jennings GL, Dart AM. Four weeks of cycle training increases basal production of nitric oxide from the forearm. Am J Physiol 1997: 272: H1070-H1077.

Lansley KE, Winyard PG, Bailey SJ, Vanhatalo A, Wilkerson DP, Blackwell JR, Gilchrist M, Benjamin N, Jones AM. Acute dietary nitrate supplementation improves cycling time trial performance. Med Sci Sports Exerc 2011a: 43: 1125-1131.

Lansley KE, Winyard PG, Fulford J, Vanhatalo A, Bailey SJ, Blackwell JR, DiMenna FJ, Gilchrist M, Benjamin N, Jones AM. Dietary nitrate supplementation reduces the $\mathrm{O} 2$ cost of walking and running: a placebo-controlled study. J Appl Physiol 2011b: 110: 591-600.

Larsen FJ, Schiffer TA, Borniquel S, Sahlin K, Ekblom B, Lundberg JO, Weitzberg E. Dietary inorganic nitrate improves mitochondrial efficiency in humans. Cell Metab 2011: 13: 149-159.

Larsen FJ, Schiffer TA, Weitzberg E, Lundberg JO. Regulation of mitochondrial function and energetics by reactive nitrogen oxides. Free Radic Biol Med 2012: 53: 1919-1928.

Levett DZ, Fernandez BO, Riley HL, Martin DS, Mitchell K, Leckstrom CA, Ince C, Whipp BJ, Mythen MG, Montgomery HE, Grocott MP, Feelisch $M$. The role of nitrogen oxides in human adaptation to hypoxia. Sci Rep 2011: 1: 109 .

Limberg JK, Harrell JW, Evans TD, Johansson RE, Ciancio DJ. Ageing uncompensated: exercise, nitric oxide and hypoxia. J Physiol 2011: 589: 2923-2924.

Lowry OH, Passoneau JV. A flexible system of enzymatic analysis. New York: Academic Press, 1972.

Maiorana A, O'Driscoll G, Taylor R, Green D. Exercise and the nitric oxide vasodilator system. Sports Med 2003: 33: 1013-1035.

Manukhina EB, Downey HF, Mallet RT. Role of nitric oxide in cardiovascular adaptation to intermittent hypoxia. Exp Biol Med (Maywood) 2006: 231: 343-365.

Masschelein E, Van TR, Wang X, Van SA, Thomis M, Hespel P. Dietary nitrate improves muscle but not cerebral oxygenation status during exercise in hypoxia. J Appl Physiol 2012: 113: 736-745.

Millet GP, Roels B, Schmitt L, Woorons $\mathrm{X}$, Richalet JP. Combining hypoxic methods for peak performance. Sports Med 2010: 40: 1-25.

Mitek M, Anyzewska A, Wawrzyniak A. Estimated dietary intakes of nitrates in vegetarians compared to a traditional diet in Poland and acceptable daily intakes: is there a risk? Rocz Panstw Zakl Hig 2013: 64: 105-109.

Muggeridge DJ, Howe CC, Spendiff O, Pedlar C, James PE, Easton CA. Single dose of beetroot juice enhances cycling performance in simulated altitude. Med Sci Sports Exerc 2014: 46: 143-150.

Nussler AK, Glanemann M, Schirmeier A, Liu L, Nussler NC. Fluorometric measurement of nitrite/nitrate by 2,3-diaminonaphthalene. Nat Protoc 2006: 1: 2223-2226.

Parolin ML, Spriet LL, Hultman E, Hollidge-Horvat MG, Jones NL, Heigenhauser GJ. Regulation of glycogen phosphorylase and PDH during exercise in human skeletal muscle during hypoxia. Am J Physiol Endocrinol Metab 2000: 278: E522-E534.

Puype J, Van PK, Raymackers JM, Deldicque L, Hespel P. Sprint interval training in hypoxia stimulates glycolytic enzyme activity. Med Sci Sports Exerc 2013: 45: 2166-2174.

Richter EA, Ruderman NB. AMPK and the biochemistry of exercise: implications for human health and disease. Biochem J 2009: 418: 261-275.

Stamler JS, Meissner G. Physiology of nitric oxide in skeletal muscle. Physiol Rev 2001: 81: 209-237.

Umbrello M, Dyson A, Feelisch M, Singer M. The key role of nitric oxide in hypoxia: hypoxic vasodilation and energy supply-demand matching. Antioxid Redox Signal 2013: 19: 1690-1710.

Vandesompele J, De Preter K, Pattyn F, Poppe B, Van Roy N, De Paepe A, Speleman F. Accurate normalization of real-time quantitative RT-PCR data by geometric averaging of multiple internal control genes. Genome Biol 2002: 3: RESEARCH0034.

Vanhatalo A, Bailey SJ, Blackwell JR, DiMenna FJ, Pavey TG, Wilkerson DP, Benjamin N, Winyard PG, Jones AM. Acute and chronic effects of dietary nitrate supplementation on blood pressure and the physiological responses to moderate-intensity and incremental exercise. Am J Physiol Regul Integr Comp Physiol 2010: 299: R1121-R1131.

Vanhatalo A, Fulford J, Bailey SJ, Blackwell JR, Winyard PG, Jones AM. Dietary nitrate reduces muscle metabolic perturbation and improves exercise tolerance in hypoxia. J Physiol 2011: 589: 5517-5528.

Vogt M, Puntschart A, Geiser J, Zuleger C, Billeter R, Hoppeler H. Molecular adaptations in human skeletal muscle to endurance training under simulated hypoxic conditions. J Appl Physiol 2001: 91: 173-182.

Weitzberg E, Lundberg JO. Novel aspects of dietary nitrate and human health. Annu Rev Nutr 2013: 33 : 129-159.

Wylie LJ, Kelly J, Bailey SJ, Blackwell JR, Skiba PF, Winyard PG, Jeukendrup AE, Vanhatalo A, Jones AM. Beetroot juice and exercise: pharmacodynamic and dose-response relationships. J Appl Physiol (1985) 2013: 115: 325-336.

Zoll J, Ponsot E, Dufour S, Doutreleau S, Ventura-Clapier R, Vogt M, Hoppeler H, Richard R, Fluck M. Exercise training in normobaric hypoxia in endurance runners. III. Muscular adjustments of selected gene transcripts. J Appl Physiol 2006: 100: 1258-1266. 